\title{
Sulfur isotope ratios of ores and chemical environment of ore deposition in the Taishu Pb-Zn sulfide deposits, Japan
}

\author{
YASUHIRO KIYOSU \\ Department of Earth Sciences, Faculty of Science, Nagoya University \\ Chikusa, Nagoya 464, Japan
}

(Received October 17, 1975; accepted in revised form November 29, 1976)

\begin{abstract}
Sulfur isotopic compositions of sulfide minerals from mesothermal fissure-filling ore deposits of the Taishu mine have been investigated. The $\delta^{34} \mathrm{~S}$ values of 65 sulfide samples range from +2.7 to +6.4 permil, giving an average of +4.4 permil. Sulfide minerals exhibit a decreasing trend of $\delta^{34} \mathrm{~S}$ values: sphalerite $>$ pyrrhotite $>$ galena. Sulfur isotope temperatures estimated from sulfur isotopic fractionation between sphalerite and galena are $300^{\circ}$ to $350^{\circ} \mathrm{C}$, which agree with the maximum value of fluid inclusion temperature for quartz.

From sulfur isotopic evidences and chemical equilibrium concept of ore deposition, it is suggested that the chemical condition of ore-forming fluid was restricted to low $\mathrm{fO}_{2}$ and neutrality.

The mean $\delta^{34} \mathrm{~S}$ value of sulfide minerals for each vein was found to increase from the early to the late vein. This progressive ${ }^{34} \mathrm{~S}$ enrichment is presumably due to the $\mathrm{pH}$ change in ore-forming fluid during ore deposition.
\end{abstract}

\section{INTRODUCTION}

Sulfur isotopic study of hydrothermal ore deposits is useful for disclosing the genesis of sulfide ores. Recently, the origin of sulfur in ore deposits and physicochemical conditions of ore deposition such as temperature, $\mathrm{pH}, \mathrm{fO}_{2}$ and $\mathrm{fS}_{2}$ have been discussed from isotopic distributions of ore deposits on the basis of geological, mineralogical and geochemical data (KAJIWARA, 1971; ОНMOTO, 1972; ROBINSON and Онмото, 1973; Robinson and B ADHAM, 1973; RYE and SAwKINS, 1974). The distribution of sulfur isotopes in vein type ore deposits, however, has not been studied in detail with respect to many hydrothermal ore deposits. Taishu lead-zinc ore deposits for which vein structure, mineral paragenesis and fluid inclusion have been investigated are selected here to study isotopically the genesis of mesothermal vein type deposits.

In the present paper, sulfur isotopic distribution of mesothermal lead-zinc vein deposits of the Taishu mine is examined, and on the basis of these data an attempt is made to estimate isotopic temperatures and chemical conditions $\left(\mathrm{pH}, \mathrm{fO}_{2}\right)$ and to clarify depositional process.

\section{Geological Setting}

The Taishu mine, which consists of mesothermal zinc and lead sulfide veins, is located in the west of Tsushima island which lies between Kyushu and the Korean Peninsula. The geology and ore deposits of the Taishu mine have been described by UeHara (1959), UeHara and Matsuhashi (1961) and Imai et al. (1971).

Tsushima island consists mostly of sandstone, shale and their alternation facies belonging to the Taishu formation of Paleogene age. In the south of the island, the Uchiyama granitic batholith dated to be 12 million years (KAWANO and UEDA, 1966) is exposed in an area of $12 \mathrm{~km}^{2}$, with its long axis trending $\mathrm{N} 30^{\circ}-40^{\circ} \mathrm{E}$. The granite intruded into sedimentary rocks, converting them to hornfels. Sheets or dikes of quartz porphyry or porphyrite cut by the granite are found throughout the island.

The principal ore deposits of the mine occurring around the western part of the granite mass form mesothermal fissure-filling pyrrhotitesphalerite-galena veins. Vein fissures are classified into bedding reverse faults (e.g., Senninmabu vein) striking $\mathrm{N} 25^{\circ}-45^{\circ} \mathrm{E}$ and dipping $20^{\circ}-40^{\circ} \mathrm{SE}$ and the strike-slip faults (e.g., Himi vein) striking $\mathrm{N} 20^{\circ} \mathrm{E}-\mathrm{N} \quad 15^{\circ} \mathrm{W}$ and dipping $50^{\circ}-70^{\circ} \mathrm{E}$ as shown in Fig. 1. Imalet al. (1971) 


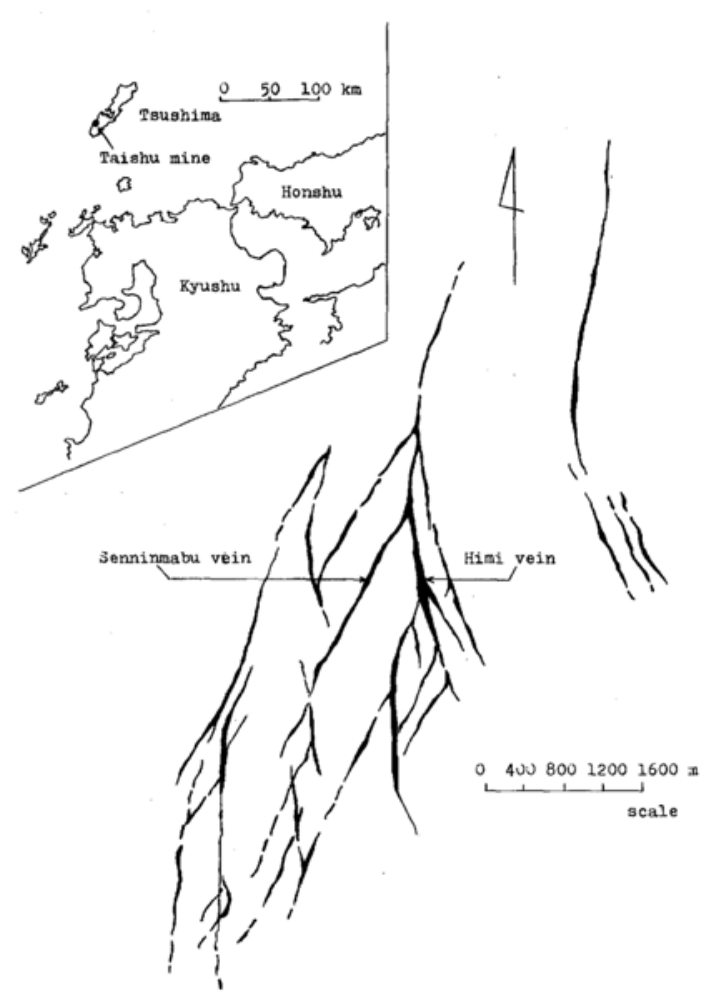

Fig. 1. Location of Taishu mine (inset) and vein systems, where samples were collected.

suggested that these two kinds of faults constituted major paths of the ore-forming fluid originated from the granitic magma. Zonal arrangement of minerals is remarkable in these veins. The Himi vein, however, lacks the lower parts of mineral zoning. The following mineral zoning can be recognized from lower to upper parts of the veins: quartz-pyrrhotite (locally containing chalcopyrite)-sphaleritegalena-calcite.

MATSUHASHI (1968) suggested that the oreforming fluid ascended along the bedding reverse faults and further moved into the strike-slip faults.

Hydrothermal alteration of the country rock is very weak. Alteration minerals consist of chlorite, sericite and carbonate.

\section{EXPERIMENTAL}

Sample collection 43 sulfide samples were collected from levels of $-280 \mathrm{~m}$ to $0 \mathrm{~m}$ of the Senninmabu vein. They consist mostly of sphalerite, galena and pyrrhotite. 22 samples were collected also from levels of $-280 \mathrm{~m}$ to $0 \mathrm{~m}$ of the Himi vein. The localities where these samples were collected are shown in Fig. 1.

All samples were examined for alteration minerals and texture under a microscope. The sulfide minerals were purified by magnetic separation or handpicking under a microscope.

Isotope analysis of sulfur Sphalerite and galena were treated with concentrated $\mathrm{HCl}$. The evolved $\mathrm{H}_{2} \mathrm{~S}$ was precipitated as $\mathrm{CdS}$, then converted to $\mathrm{Ag}_{2} \mathrm{~S}$ and burnt to $\mathrm{SO}_{2}$ at a temperature of $1,150^{\circ}$ to $1,200^{\circ} \mathrm{C}$ in a stream of $\mathrm{CO}_{2}$-free air. Pyrrhotite was combusted directly to $\mathrm{SO}_{2}$. Sulfur isotopic ratios of $\mathrm{SO}_{2}$ were determined on a duall collector mass spectrometer. They are expressed as $\delta^{34} \mathrm{~S}$ values in permil defined as:

$\delta^{34} \mathrm{~S}=\left[\left({ }^{34} \mathrm{~S} /{ }^{32} \mathrm{~S}\right)\right.$ sample $/\left({ }^{34} \mathrm{~S} /{ }^{32} \mathrm{~S}\right)$ standard 1] $\times 10^{3}$. The standard is the troilite sulfur of the Canyon Diablo meteorite. The analytical error determined by multiple analyses of a working standard is \pm 0.2 permil.

Iron content analysis Iron content of pyrrhotite was analyzed by X-ray diffraction method of ARNOLD (1962). FeS content of sphalerite was analyzed by means of X-ray diffraction analyses (BARTON and TOULMIN, 1966).

\section{RESUlTS AND Discussion}

Sulfur isotopic compositions of sulfide minerals from the Taishu mine are listed in Table 1. The $\delta^{34} \mathrm{~S}$ values determined for 65 sulfide samples range from +2.7 to +6.4 permil and the average is +4.4 permil. The sphalerite sulfur has $\delta^{34} \mathrm{~S}$ values ranging from +3.9 to +6.4 permil. The sulfur isotopic composition of pyrrhotite ranges from $\delta^{34} \mathrm{~S}$ of +3.4 to +4.8 permil. Galena has $\delta^{34} \mathrm{~S}$ values ranging from +2.7 to +4.7 permil.

Isotopic geothermometry Fractionation of sulfur isotopes between coexisting sulfide minerals has been examined for sphalerite-pyrrhotite and sphalerite-galena pairs, and the results are shown in Fig. 2. Sphalerite is always enriched in ${ }^{34} \mathrm{~S}$ relative to the associated galena. The $\delta^{34} \mathrm{~S}$ difference between sphalerite and galena is approximately 2.0 permil. Pyrrhotite is slightly more depleted in ${ }^{34} \mathrm{~S}$ than the associated sphalerite. The difference does not exceed 1.0 permil, averaging 0.4 permil. The order of ${ }^{34} \mathrm{~S}$ enrichment in the sulfide minerals is, therefore, as follows: sphalerite $>$ pyrrhotite $>$ galena. This sequence is consistent with the 
Table 1. Sulfur isotopic composition of sulfide minerals from Taishu deposits

\begin{tabular}{|c|c|c|c|c|c|}
\hline \multirow{2}{*}{ Sample No. } & \multicolumn{2}{|c|}{ Location } & \multicolumn{2}{|c|}{$\delta^{34} \mathrm{~S}$} & \multirow{2}{*}{$\begin{array}{c}(\%) \\
\text { Po }\end{array}$} \\
\hline & Vein & Level & $\mathrm{Sp}$ & Gn & \\
\hline 035 & Senninmabu & $0 \mathrm{~m}$ & +6.1 & +3.8 & \\
\hline 003 & $"$ & $-210 \mathrm{~m}$ & +5.0 & +3.2 & \\
\hline 006 & $"$ & $n$ & +5.0 & +3.3 & \\
\hline 008 & $"$ & $n$ & +4.7 & +3.1 & \\
\hline 010 & $"$ & $"$ & +5.6 & +3.8 & +4.8 \\
\hline 011 & $"$ & $"$ & +4.4 & & \\
\hline 012 & $"$ & $n$ & +4.4 & & +3.9 \\
\hline 028 & $"$ & $"$ & +4.5 & & +3.9 \\
\hline 072 & $"$ & " & +4.7 & & +4.2 \\
\hline 013 & $"$ & $-245 \mathrm{~m}$ & +4.5 & & +4.1 \\
\hline 026 & $"$ & " & +4.4 & +2.7 & +4.4 \\
\hline 014 & $"$ & $-280 \mathrm{~m}$ & +4.5 & & +3.7 \\
\hline 015 & $"$ & $"$ & +4.7 & +3.2 & \\
\hline 017 & $"$ & $"$ & & & +3.4 \\
\hline 018 & $"$ & $"$ & +5.0 & +3.2 & \\
\hline 020 & $"$ & $"$ & +4.8 & +3.4 & +4.5 \\
\hline 021 & $"$ & $"$ & & & +4.5 \\
\hline 023 & $"$ & $"$ & +4.5 & & \\
\hline 027 & $"$ & $"$ & +4.4 & +3.1 & +4.1 \\
\hline 051 & $"$ & $"$ & +5.3 & +3.3 & +4.6 \\
\hline 052 & $"$ & $"$ & +3.9 & +2.9 & \\
\hline 036 & Himi & $0 \mathrm{~m}$ & +5.6 & +3.9 & \\
\hline 038 & $"$ & $-70 \mathrm{~m}$ & +5.8 & +4.1 & \\
\hline 041 & $"$ & $-105 \mathrm{~m}$ & +5.2 & +4.1 & \\
\hline 042 & $"$ & " & +5.3 & +4.1 & \\
\hline 030 & $"$ & $-140 \mathrm{~m}$ & +6.0 & +3.6 & \\
\hline 032 & $"$ & " & +5.3 & +3.2 & \\
\hline 033 & $"$ & $"$ & +4.6 & & +4.7 \\
\hline 044 & $"$ & " & +6.1 & +4.3 & \\
\hline 001 & $"$ & $-210 \mathrm{~m}$ & +6.4 & +4.7 & \\
\hline 045 & $"$ & " & +5.7 & +3.9 & \\
\hline 046 & $"$ & $"$ & +6.4 & +4.4 & \\
\hline
\end{tabular}

Sp: Sphalerite Gn: Galena

Po: Pyrrhotite

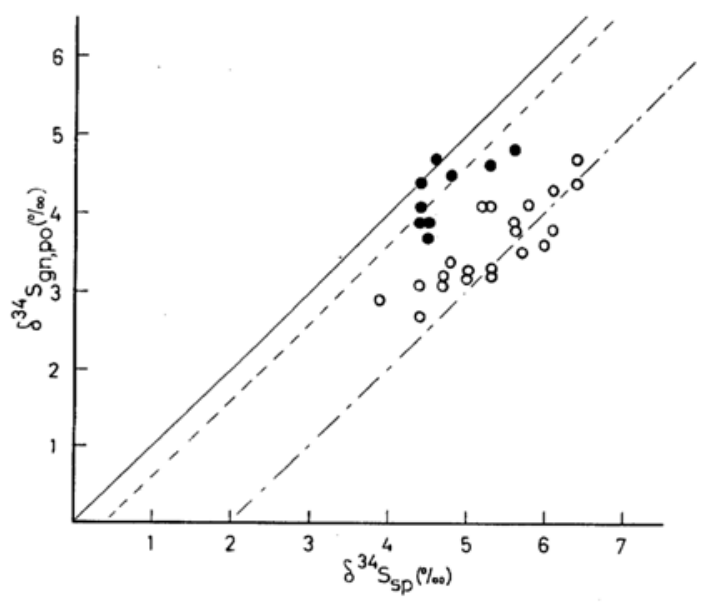

Fig. 2. Plot of $\delta^{34} S$ values for galena and pyrrhotite versus sphalerite.

Open and solid circles indicate galena versus sphalerite and pyrrhotite versus sphalerite, respectively. Dashed and dotted lines represent 2.0 and 0.4 permil difference in $\delta^{34} S$ values from those of coexisting sphalerite, respectively. predicted trend (S AKAI, 1968; BACHINSKI, 1969). The constancy of isotopic fractionation between coexisting sulfide minerals indicates attainment of isotopic equilibrium at an almost uniform temperature.

The distribution of sulfur isotopes between sphalerite and galena can be expressed by

$$
\begin{aligned}
& Z^{32} \mathrm{~S}+\mathrm{Pb}^{34} \mathrm{~S}=\mathrm{Zn}^{34} \mathrm{~S}+\mathrm{Pb}^{32} \mathrm{~S} \\
& \alpha_{\text {sp }-\mathrm{gn}}=\frac{1+\delta^{34} \mathrm{~S}_{\mathrm{sp}} \times 10^{-3}}{1+\delta^{34} \mathrm{~S}_{\mathrm{gn}} \times 10^{-3},}
\end{aligned}
$$

where $\alpha_{\mathrm{sp}-\mathrm{gn}}$ is fractionation factor between sphalerite and galena. If $\alpha$ is close to unity,

$$
1,000 \ln \alpha_{\mathrm{sp}-\mathrm{gn}} \cong \delta^{34} \mathrm{~S}_{\mathrm{sp}}-\delta^{34} \mathrm{~S}_{\mathrm{gn}}=\Delta_{\mathrm{sp}-\mathrm{gn}}
$$

The equilibrium fractionation factor between sphalerite and galena is available from both 
theoretical and experimental studies (SAKAI, 1968; GrootenboRE and SCHWARCZ, 1969; KAJIWARA and Krouse, 1971; KIYOSU, 1973; CZAMANSKE and RYE, 1974). According to the experimental work by the present author (KIYOSU, 1973), the equilibrium fractionation between sphalerite and galena is related to temperature as follows:

$$
\ln \alpha_{\mathrm{sp}-\mathrm{gn}}=891 \mathrm{~T}^{-2}-0.00057
$$

where $\mathrm{T}$ denotes absolute temperature. This experimental scale is nearly consistent with that by KaJIWARA and Krouse (1971). Using this equation, we get isotopic equilibrium temperatures for sphalerite-galena pairs from the Senninmabu and Himi veins as given in Table 2.

Table 2. Delta values for sulfide pairs and isotopic temperatures

\begin{tabular}{|c|c|c|c|c|}
\hline Group & $N$ & ${ }^{* \triangle_{\mathrm{sp}-\mathrm{gn}}}$ & Range & $\begin{array}{c}\text { Mean isotopic } \\
\text { temp. }{ }^{\circ} \mathrm{C}\end{array}$ \\
\hline Senninmabu & 12 & 1.7 & $1.0-2.3$ & 340 \\
\hline $0 \mathrm{~m}$ & 1 & 2.3 & & 280 \\
\hline$-210 m$ & 4 & 1.7 & $1.6-1.8$ & 340 \\
\hline$-245 m$ & 1 & 1.7 & & 340 \\
\hline$-280 \mathrm{~m}$ & 6 & 1.7 & $1.0-2.0$ & 340 \\
\hline Himi & 10 & 1.8 & $1.2-2.4$ & 330 \\
\hline $0 \mathrm{~m}$ & 1 & 1.7 & & 340 \\
\hline$-70 \mathrm{~m}$ & 1 & 1.7 & & 340 \\
\hline$-105 \mathrm{~m}$ & 2 & 1.2 & $1.1-1.2$ & 440 \\
\hline$-140 \mathrm{~m}$ & 3 & 2.0 & $1.7-2.4$ & 320 \\
\hline$-210 \mathrm{~m}$ & 3 & 2.1 & $1.8-2.2$ & 310 \\
\hline
\end{tabular}

${ }^{*} \Delta_{s p-g n}=\delta^{34} S_{s p}-\delta^{34} S_{g n} \dot{\approx} 10^{3} \ln \alpha_{s p-g n}$

The isotopic temperatures obtained range from $280^{\circ}$ to $400^{\circ} \mathrm{C}$, and the average temperatures for the Senninmabu and Himi veins are estimated to be $340^{\circ}$ and $330^{\circ} \mathrm{C}$, respectively. The temperature of formation of the Senninmabu vein is nearly the same as that of the Himi vein. TAKENOUCHI (1962) reported that the temperature of deposition deduced from fluid inclusion studies of quartz and calcite veins in the Taishu mine ranged from $290^{\circ}$ to $320^{\circ} \mathrm{C}$. The maximum filling temperature nearly agrees with the average isotopic temperature. Isotopic temperatures based on the experimental scale of GROOTENBORE and SCHWARCZ (1969) and CzAmANSKe and Rye (1974), however, are lower than these filling temperatures. Therefore, it would be assumed that the sulfide minerals of the Taishu deposits were precipitated at around $300^{\circ} \mathrm{C}$.

Chemical environment of ore deposition Pyrrhotite in the Senninmabu vein is hexagonal, monoclinic or mixtures of them, whereas in the Himi vein it is hexagonal (Table 3). The range of iron content determined by the X-ray diffraction method of ARNOLD (1962) is narrow throughout the vein and independent of crystal systems. The fugacity of sulfur can be calculated from the pyrrhotite composition (ToulmiN and BARTON, 1964). Therefore, the fugacity of sulfur was presumably constant during pyrrhotite deposition in both veins. On the other hand, fugacity of sulfur can be estimated also from $\mathrm{FeS}$ content of sphalerite coexisting with pyrrhotite. FeS content of the sphalerite analyzed by the X-ray diffraction technique (BARTON and Toulmin, 1966) is also narrow in range and high, mostly from 25.0 to 27.0 mole percent (Table 4). The FeS content of sphalerite from the Senninmabu vein is similar to that from the Himi vein. The former contains about 24.0 mole percent $\mathrm{FeS}$, while the latter about

Table 3. Iron content and crystal system of pyrrhotite

\begin{tabular}{cccc}
\hline \hline No. & Vein & Crystal form & Fe atomic \% \\
\hline 010 & Senninmabu & H & 47.3 \\
012 & $"$ & Mix & 47.0 \\
072 & $"$ & H & 47.3 \\
013 & $"$ & Mix & 47.3 \\
026 & $"$ & H & 47.3 \\
014 & $"$ & Mix & 47.1 \\
020 & $"$ & Mix & 47.0 \\
021 & $"$ & Mix & 47.1 \\
027 & $"$ & M & 47.0 \\
051 & $"$ & H & 47.3 \\
033 & Himi & H & 47.4 \\
& & & av. $47.3 \pm 0.15$
\end{tabular}

H: Hexagonal M: Monoclinic

Mix: Hexagonal + Monoclinic

Table 4. FeS content of sphalerite

\begin{tabular}{lccccc}
\hline \hline No. & Vein & FeS mol.(\%) & No. & Vein & FeS mol.(\%) \\
\hline 035 & Senninmabu & 20.4 & 036 & Himi & 20.4 \\
003 & $\prime$ & 25.0 & 038 & $"$ & 26.8 \\
006 & $"$ & 20.4 & 041 & $"$ & 26.8 \\
008 & $"$ & 25.0 & 042 & $"$ & 23.6 \\
010 & $"$ & 23.6 & 030 & $"$ & 23.6 \\
026 & $\prime$ & 23.6 & 032 & $"$ & 23.6 \\
015 & $"$ & 23.6 & 044 & $"$ & 30.4 \\
018 & $"$ & 25.0 & 001 & $"$ & 30.4 \\
020 & $"$ & 26.8 & 045 & $"$ & 26.8 \\
027 & $"$ & 25.0 & 046 & $"$ & 23.6 \\
051 & $"$ & 26.8 & & & av. $25.6 \pm 1.2$ \\
052 & $"$ & 25.0 & & & \\
& & av. $24.2 \pm 1.2$ & & & \\
\hline
\end{tabular}


25.0 mole percent $\mathrm{FeS}$. In the case of the Senninmabu vein, FeS content of early stage sphalerite which coexists with pyrrhotite and quartz, is similar to that of late stage sphalerite which coexists with galena and calcite. This suggests that the sulfur fugacity has been constant from lower to upper parts of this vein during ore deposition.

The average value of $\mathrm{fS}_{2}$ obtained from the iron content of pyrrhotite is $10^{-12.0} \mathrm{~atm}$ at $300^{\circ} \mathrm{C}$. A similar value can be calculated also from $\mathrm{FeS}$ content of sphalerite.

Stability relations of minerals in the Fe-S-O system can be shown on a $\mathrm{fS}_{2}-\mathrm{fO}_{2}$ diagram (Fig. 3). This diagram is constructed with data given by Holland (1965) and Helgeson (1969). The fugacity of sulfur obtained lies near the boundary between pyrite and pyrrhotite stability fields in a $\mathrm{fS}_{2}-\mathrm{fO}_{2}$ diagram for the $\mathrm{Fe}-\mathrm{S}$ $\mathrm{O}$ system. Maximum oxygen fugacity of pyritepyrrhotite boundary on the $\mathrm{fS}_{2}-\mathrm{fO}_{2}$ diagram is pyrite-pyrrhotite-magnetite triple point as shown in Fig. 3. The absence of $\mathrm{FeS}_{2}-\mathrm{FeS}-\mathrm{Fe}_{3} \mathrm{O}_{4}$ assemblage in Taishu deposits, however, suggests that the oxygen fugacity was always below the triple point. On the other hand, the presence of calcite and quartz in these deposits shows that the oxygen fugacity was higher than that of wollastonite and graphite-calcite and quartz phase boundary. This boundary can be constructed from the following reaction:

$$
\mathrm{CaSiO}_{3}+\mathrm{C}+\mathrm{O}_{2}=\mathrm{CaCO}_{3}+\mathrm{SiO}_{2}
$$

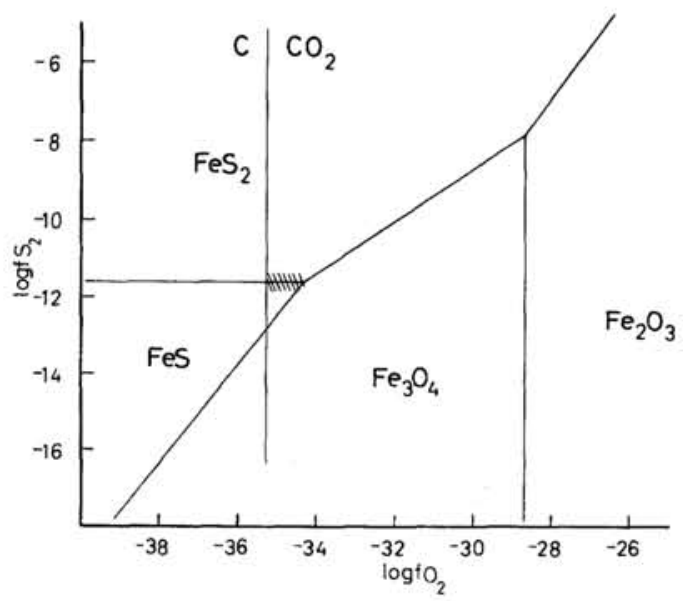

Fig. 3. A $\mathrm{fS}_{2}-\mathrm{fO}_{2}$ plot constructed for $300^{\circ} \mathrm{C}$ to show mineral stability relations in the $\mathrm{Fe}-\mathrm{S}-\mathrm{O}$ system. The vertical line at $\log \mathrm{fO}_{2}=-35.3 \mathrm{~atm}$ represents the $\mathrm{C}-\mathrm{CO}_{2}$ boundary at $\log \mathrm{fCO}_{2}=0.67 \mathrm{~atm}$. The hatched area shows the probable stability field for the ore-forming fluids.
Thus, the upper and lower $\mathrm{fO}_{2}$ limits of deposition are given by this triple point and the $\mathrm{CaSiO}_{3}, \mathrm{C}-\mathrm{CaCO}_{3}, \mathrm{SiO}_{2}$ boundary, respectively. The most probable $\mathrm{fS}_{2}$ and $\mathrm{fO}_{2}$ values of the ore-forming fluid is shown by the hatched area in Fig. 3. The oxygen fugacity in the oreforming fluid, therefore, has a range of $10^{-34.4}$ to $10^{-35.3} \mathrm{~atm}$.

The stability field of sericite is useful to estimate the $\mathrm{pH}$ range of ore-forming fluid, when temperature and $\mathrm{K}^{+}$concentration of the system are known. In the Taishu deposits, sericite occurs in a small amount. The stability field of sericite can be constructed from the following reactions:

$$
\begin{aligned}
& 3 \mathrm{KAl}_{3} \mathrm{Si}_{3} \mathrm{O}_{8}+2 \mathrm{H}^{+}= \mathrm{KAl}_{3} \mathrm{Si}_{3} \mathrm{O}_{10}(\mathrm{OH})_{2} \\
&+6 \mathrm{SiO}_{2}+2 \mathrm{~K}^{+} \\
& 2 \mathrm{KAl}_{3} \mathrm{Si}_{3} \mathrm{O}_{10}(\mathrm{OH})_{2}+2 \mathrm{H}^{+}+3 \mathrm{H}_{2} \mathrm{O} \\
&=3 \mathrm{Al}_{2} \mathrm{Si}_{2} \mathrm{O}_{5}(\mathrm{OH})_{4}+2 \mathrm{~K}^{+}
\end{aligned}
$$

Potassium ion concentration in an ore-forming fluid can be estimated with data of fluid inclusions (e.g., Онмото, 1970). Data on potassium ion concentration for fluid inclusions, however, is unfortunately unknown for the Taishu deposits. Taking account of Онмото's data, we assume the concentration of potassium ions in an ore-forming fluid to be $10^{-3} \mathrm{M}$ in this study. Activity coefficient of ionic species are estimated from the Debye-Hückel equation. ImAI et al. (1971) reported that the $\mathrm{NaCl}$ salinity of inclusion from the vein quartz in these deposits is about 30 weight percent. When the oreforming fluid is assumed to be this $\mathrm{NaCl}$ solution, its ionic strength is then calculated to be 1.36. Then the boundary of stable region for sericite and kaolinite is estimated to be $\mathrm{pH} 6.4$ at $300^{\circ} \mathrm{C}$, whereas the boundary of sericite and $\mathrm{K}$-feldspar is $\mathrm{pH} 7.5$. Therefore, the $\mathrm{pH}$ at the time of ore deposition is estimated to be 6.4 to 7.5 according to the stability field of sericite.

Asuming that reactions in the system were close to equilibrium, we get the concentrations of dissolved sulfur species from the following reactions:

$$
\begin{aligned}
& \mathrm{H}_{2} \mathrm{~S}+\frac{1}{2} \mathrm{O}_{2}=\mathrm{H}_{2} \mathrm{O}+\frac{1}{2} \mathrm{~S}_{2} \\
& \mathrm{H}_{2} \mathrm{~S}=\mathrm{H}^{+}+\mathrm{HS}^{-}
\end{aligned}
$$




$$
\begin{aligned}
& \mathrm{HS}^{-}=\mathrm{H}^{+}+\mathrm{S}^{2-} \\
& 2 \mathrm{H}^{+}+\mathrm{SO}_{4}^{2-}=\mathrm{H}_{2} \mathrm{~S}+2 \mathrm{O}_{2} \\
& \mathrm{HSO}_{4}^{-}=\mathrm{H}^{+}+\mathrm{SO}_{4}^{2-}
\end{aligned}
$$

The equilibrium constants for the reaction (4) (5) (7) (8) and (6) at $300^{\circ} \mathrm{C}$ can be taken from Helgeson (1969) and Ellis and GigGenbaCH (1971), respectively. Concentrations of dissolved sulfur species in the ore-forming fluid at $300^{\circ} \mathrm{C}$ are presented in Table 5. The concentration of total dissolved sulfur species at the time of formation of both veins is in a range from $10^{-2.5}$ to $10^{-2.0} \mathrm{M}$. Hydrogen sulfide is dominant among sulfur species in the ore-forming fluid.

Table 5. Concentrations of dissolved sulfur species in ore-forming fluid

\begin{tabular}{ll|c|c|c|c}
\hline \hline \multicolumn{1}{l|}{$\log \mathrm{fS}_{2}$} & \multicolumn{5}{c}{-11.6} \\
\hline $\log \mathrm{fO}_{2}$ & & \multicolumn{2}{|c}{-35.3} & \multicolumn{2}{c}{-34.4} \\
\hline $\mathrm{pH}$ & & 6.4 & 7.6 & 6.4 & 7.6 \\
\hline & $\mathrm{H}_{2} \mathrm{~S}$ & -2.04 & -2.29 & -2.49 & -2.74 \\
& $\mathrm{HS}^{-}$ & -2.99 & -2.04 & -3.44 & -2.49 \\
$\log \mathrm{M}$ & $\mathrm{S}^{2-}$ & -7.18 & -5.04 & -7.64 & -5.07 \\
& $\mathrm{HSO}_{4}^{-}$ & -9.66 & -8.71 & -8.31 & -7.11 \\
& $\mathrm{SO}_{4}^{2-}$ & -8.90 & -6.75 & -7.55 & -5.15 \\
\hline
\end{tabular}

M: $\mathrm{mol} / 1$

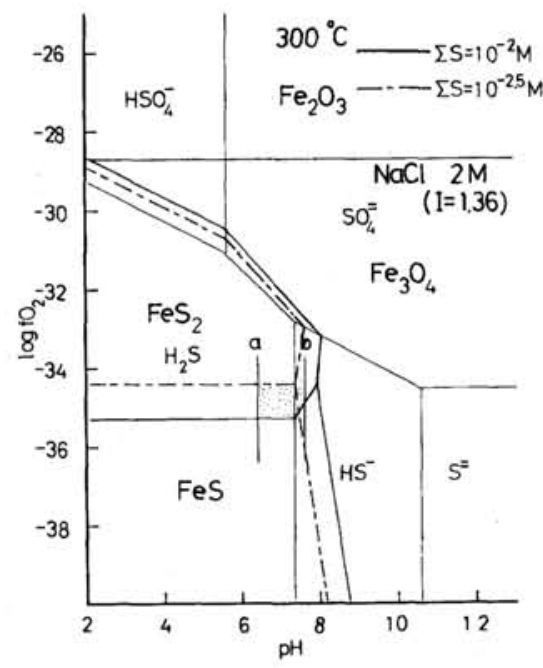

Fig. 4. Stability fields of iron oxides, iron sulfides and aqueous solution constructed from the thermodynamic data at $300^{\circ} \mathrm{C}$ provided by HELGESON (1969).

$a$ and $b$ represent the kaolinite/sericite and sericite $/ K$ feldspar stability boundaries in a solution containing $10^{-3}$ mole $K^{+}$ions $/ l$, respectively. Shaded zone where sericite is stable indicates the field of sulfide minerals in the Taishu deposits.
Observed $\delta^{34} \mathrm{~S}$ variation of sulfide minerals suggests that the chemical environment of ore deposition was nearly unchanged. The stability relationships of sulfide minerals and chemical state of the ore-forming fluid with given total sulfur can be shown on a $\log \mathrm{fO}_{2}-\mathrm{pH}$ diagram. The stability fields of $\mathrm{Fe}-\mathrm{S}-\mathrm{O}$ minerals at $300^{\circ} \mathrm{C}$ for concentration of total dissolved sulfur species of $10^{-2.0}$ and $10^{-2.5} \mathrm{M}$ are shown on a $\log \mathrm{fO}_{2}$-pH diagram (Fig. 4). The probable area of sulfide deposition for these ore deposits is clearly within the $\mathrm{H}_{2} \mathrm{~S}-\mathrm{HS}^{-}$predominant field.

Fractionation during ore deposition The Senninmabu vein can be divided into four zones, i.e. pyrrhotite, pyrrhotite-(sphalerite), sphaleritepyrrhotite, and sphalerite-galena-(pyrrhotite) zones. The Himi vein comprises only sphaleritegalena-(pyrrhotite) zone. Figure 5 shows the isotopic data for each zone in the Senninmabu vein. It is seen that the average $\delta^{34} \mathrm{~S}$ values of each sulfide species slightly increase toward the later stage of ore deposition. For example, the average $\delta^{34} \mathrm{~S}$ value of sphalerite increases gradually from the lower to the upper zone in the vein as follows: +4.5 permil in the pyrrhotite zone, +4.5 permil in the sphalerite-pyrrhotite zone and +5.0 permil in the sphalerite-galena-(pyrrhotite) zone. Pyrrhotite and galena also show a variation trend similar to sphalerite.

Figure 6 shows the sulfur isotopic variation in different veins of the Taishu deposits. It is seen that $\delta^{34} \mathrm{~S}$ value of each sulfide species in the Himi vein is slightly heavier than that in the Senninmabu vein. MatsuHASHI (1968) suggested that after precipitating metal sulfides in the Senninmabu vein the residual ore-forming fluid

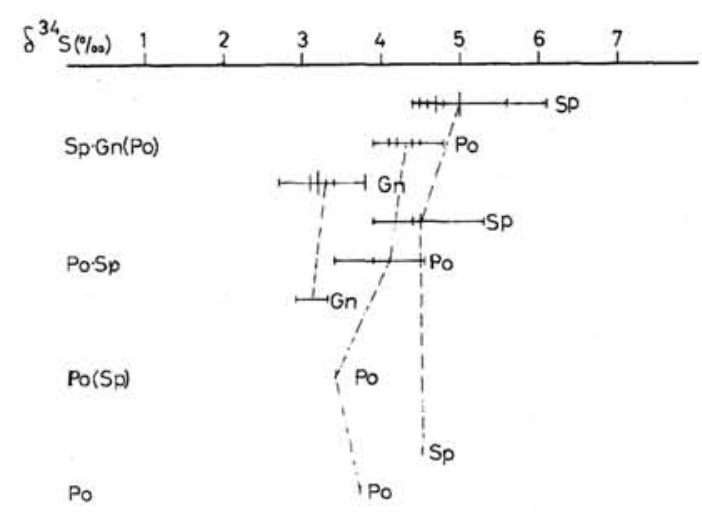

Fig. 5. Distribution of $\delta^{34} S$ values for sulfide minerals from various zones of the Senninmabu vein. Dashed lines represent the average $\delta^{34} S$ values. 


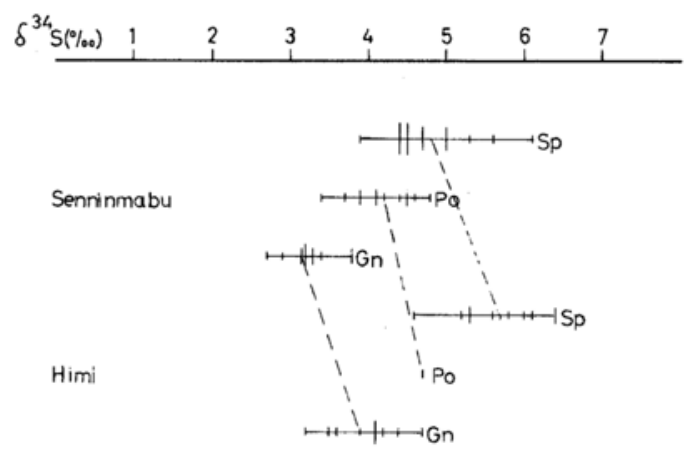

Fig. 6. Isotopic compositions of sulfide minerals in individual veins.

Dashed lines indicate the average $\delta^{34} S$ values.

moved into the Himi vein. Accepting this process, we presume that the $\delta^{34} \mathrm{~S}$ values of sulfide minerals increase from the earlier to the later vein.

The sulfur isotopic composition of sulfide minerals is controlled by the temperature of deposition, the $\mathrm{pH}$ and $\mathrm{fO}_{2}$ of ore-forming fluids, or $\delta^{34} \mathrm{~S}$ value of total sulfur and relative proportion of sulfide minerals deposited to sulfur species of ore-forming fluids (SAKAI, 1968; Онмото, 1972). As mentioned previously, the Senninmabu and Himi sulfides were precipitated from ore-forming fluid in the $\mathrm{H}_{2} \mathrm{~S}$ $\mathrm{HS}^{-}$fields at uniform $\mathrm{fO}_{2}$ and temperature. If the amount of sulfur taken out from the oreforming fluid is negligible, $\delta^{34} \mathrm{~S}$ values of sulfide minerals will change with the change in $\delta^{34} \mathrm{~S}$ value of total sulfur and $\mathrm{pH}$ of ore-forming fluid.

If we assume that in a closed system the sulfide minerals were deposited by successive supply of ore-forming fluid from a single source to both veins, $\delta^{34} \mathrm{~S}$ values of sulfide minerals in both veins would be controlled by the change in $\delta^{34} \mathrm{~S}$ values for the source of sulfur. The change in the $\delta^{34} \mathrm{~S}$ value of ore-forming fluid due to the removal of sulfide minerals is assumed to proceed according to the Rayleigh distillation formula. It is seen in Fig. 7 that the sphalerite precipitated from ore-forming fluid in the $\mathrm{H}_{2} \mathrm{~S}$ field is progressively enriched in ${ }^{34} \mathrm{~S}$ at later stages, whereas in the $\mathrm{HS}^{-}$field $\delta^{34} \mathrm{~S}$ value of sphalerite decreases toward later stage. If the above process is accepted, the sulfide minerals of both veins were successively precipitated in the $\mathrm{H}_{2} \mathrm{~S}$ field from ore-forming fluid, which is enriched in reduced sulfur, since the $\delta^{34} \mathrm{~S}$ value of sulfide species increases toward

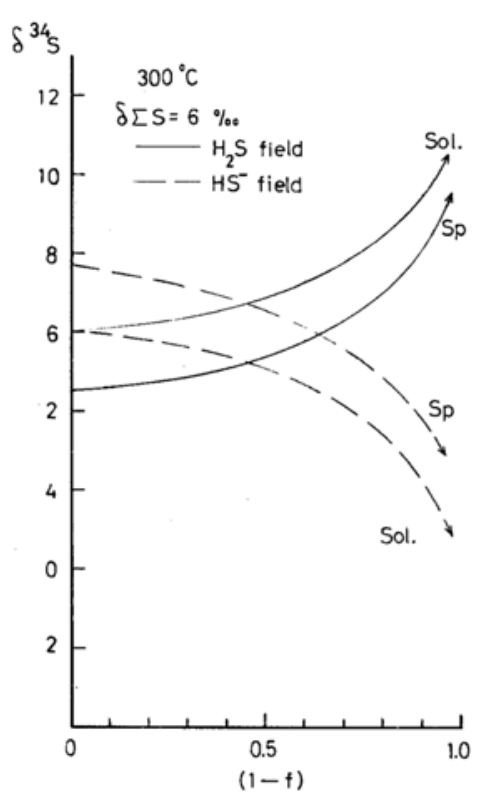

Fig. 7. Changes in $\delta^{34} S$ values of sphalerite and the total sulfur in the residual ore-forming fluid during sphalerite deposition calculated from a Rayleigh equation.

The Rayleigh distilation formula is shown as follows: $R t=R o f^{(\alpha-1)}$

where Rt refers to the ${ }^{34} S /{ }^{32} S$ ratio of the total sulfur in the residual ore-forming fluid at stage $f . \quad R o$ is the ${ }^{34} S /{ }^{32} S$ ratio in the original ore-forming fluid, $f$ is fraction of the initial ore-forming fluid remaining, and $\alpha$ is the sulfur isotope fractionation factor between sphalerite and the total sulfur $\left(\mathrm{H}_{2} \mathrm{~S}+\mathrm{HS}^{-}\right)$in the residual ore-forming fluid. The fractionation factor between sphalerite and $\mathrm{H}_{2} \mathrm{~S}$ and that between sphalerite and $H^{-}$at $300^{\circ} \mathrm{C}$ are from $S_{A K A I}(1968)$ and KIYOSU (1973).

the later stage of mineralization. In the Taishu deposits, however, $\mathrm{fS}_{2}$ and $\mathrm{fO}_{2}$ ranges are narrow and the total sulfur content of ore-forming fluid is in the order of $10^{-2} \mathrm{M}$ or less, as already mentioned. If the concentration of dissolved total sulfur in the ore-forming fluid changes from $10^{-2.0}$ to $10^{-2.5} \mathrm{M}$ according to sulfide deposition, the amount of sulfur taken out from the solution is about 30 percent of total sulfur. As shown in Fig. 7, the variation of $\delta^{34} \mathrm{~S}$ value for sphalerite is small (e.g., $\delta^{34} \mathrm{~S}$ value of sphalerite shifts from +4.5 to +5.0 permil, according to the change in the fraction of the initial ore-forming fluid from 1.0 to 0.7 ). Therefore, the observed trend of $\delta^{34} \mathrm{~S}$ values for sulfide minerals in both veins can not be explained by this model. 


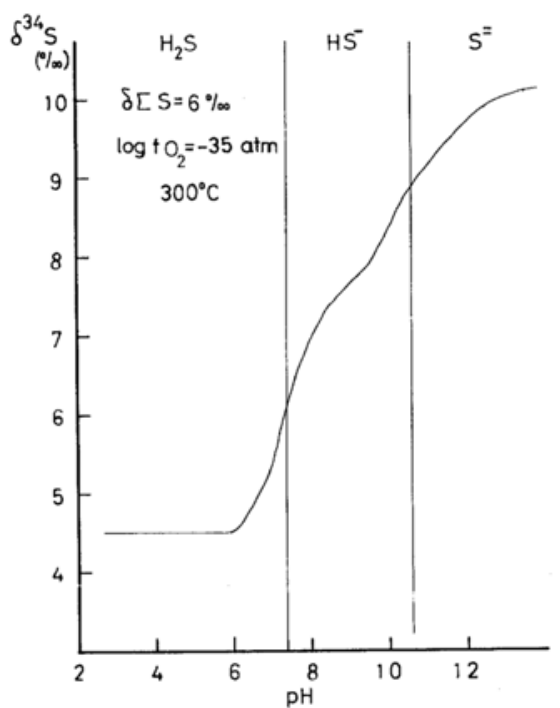

Fig. 8. $p H$ dependence of $\delta^{34} S$ value for sphalerite at $300^{\circ} \mathrm{C}$.

The isotopic composition of total sulfur is taken as 6.0 permil.

Another possible explanation for the variation of $\delta^{34} \mathrm{~S}$ values of sulfides in both veins is that small change in $\mathrm{pH}$ may result in changes in $\delta^{34} \mathrm{~S}$ values of sulfide minerals. Figure 8 shows the effect of $\mathrm{pH}$ variation on the sulfur isotopic composition of sphalerite when $\delta^{34} \mathrm{~S}$ value of total sulfur is 6.0 permil and $\mathrm{fO}_{2}$ is $10^{-35.0} \mathrm{~atm}$. The $\delta^{34} \mathrm{~S}$ value of sphalerite shifts from +4.5 to +6.0 permil according to the change in $\mathrm{pH}$ from 6 to 7 . This range of $\delta^{34} \mathrm{~S}$ variation for sphalerite is nearly consistent with that of sulfur isotope data for sphalerite in both veins. Therefore, if the $\mathrm{pH}$ value of ore-forming fluid responsible for sulfide deposition in both veins lies near the boundary between $\mathrm{H}_{2} \mathrm{~S}$ and $\mathrm{HS}^{-}$dominant fields, $\delta^{34} \mathrm{~S}$ variation of sulfide minerals deposited from this ore-forming fluid will be controlled by the $\mathrm{pH}$ changes. The $\mathrm{pH}$ of ore-forming fluid is supposed to have increased slightly toward the late stage.

\section{CONCLUSIONS}

Sulfur isotopic values of 65 sulfide minerals from the Taishu lead-zinc deposits are distributed in a relatively small range from +2.7 . to +6.4 permil. There are consistent isotopic fractionations between coexisting sulfide minerals $\left(\delta^{34} \mathrm{~S}_{\text {sphalerite }}>\delta^{34} \mathrm{~S}_{\text {pyrrhotite }}>\delta^{34} \mathrm{~S}_{\text {galena }}\right)$. Isotopic temperatures estimated with the data indicate a narrow range of depositional temperature in the mineralization processes. The sulfur isotope values also favor the conclusion that $\mathrm{pH}$ and $\mathrm{fO}_{2}$ of the ore-forming fluid experienced relatively small changes during the cource of mineralization. If chemical and isotopic equilibria had been established in the Taishu ore deposits, the stability fields of sulfide minerals would have been restricted to the low $\mathrm{fO}_{2}\left(10^{-35} \mathrm{~atm}\right)$ and neutral region $(\mathrm{pH} 6 \sim 7)$. The isotopic variation observed between fissure systems may have been produced by a slight $\mathrm{pH}$ change in ore-forming fluid.

Acknowledgment-The author is indebted to Dr. N. NAKAI of Nagoya University, for suggesting this study and for his critical discussion. The author wishes to thank Prof. H. IMAI of Tokyo University, for valuable advice and Dr. Y. KAJIWARA of Tokyo University of Education, for reading the manuscript. Thanks are also due to the staff of the Taishu mine, Tohoo Aen Co. at Tsushima, for their help in this study.

Special thanks are due to Prof. S. OANA of Nagoya University, for valuable suggestions and for reading the manuscript.

\section{REFERENCES}

ARNOLD, R. G. (1962) Equilibrium relations between pyrrhotite and pyrite from 325 to $743^{\circ} \mathrm{C}$. Econ. Geol. 57, 72-90.

BACHINSKI, D. J. (1969) Bond strength and sulfur isotopic fractionation in coexisting sulfides. ibid. 64, 56-65.

Barton, P. B. and Toulmin, P. (1966) Phase relations involving sphalerite in the Fe-Zn-S system. ibid. 61, 815-849.

CZAMANSKe, G. K. and RYe, R. O. (1974) Experimental determinations of the sphalerite-galena sulfur isotope fractionations. ibid. 69, 17-25.

Ellis, A. J. and GigGENBACH, W. (1971) Hydrogen sulphide ionization and sulphur hydrolysis in high temperature solution. Geochim. Cosmochim. Acta $31,615-620$.

Grootenbore, J. and SCHWARCZ, H. P. (1969) Temperature dependent sulfur isotope fractionation between sulfide minerals. Earth Planet. Sci. Lett. 7, $162-166$.

HELGESON, H. C. (1969) Thermodynamics of hydrothermal systems at elevated temperatures and pressures. Am. J. Sci. 267, 729-804.

HOLLAND, H. D. (1965) Some applications of thermochemical data to problems of ore deposits. 11. Mineral assemblages and the composition of oreforming fluids. Econ. Geol. 60, 1101-1166. 
ImaI, H., TAKenOUCHI, S. and Kihara, T. (1971) Fluid inclusion study at the Taishu mine, Japan, as related to geologic structure. Soc. Mining Geol. Japan, Spec. Issue 3, 321-326.

KAJIWARA, Y. (1971) Sulfur isotope study of the Kuroko-ores of the Shakanai No. 1 deposits, Akita Prefecture, Japan. Geochem. J. 4, 157-182.

KaJiwarA, Y. and KRouSE, H. R. (1971) Sulfur isotope partitioning in metallic sulfide systems. Can. J. Earth Sci. 8, 1397-1408.

KAWANO, Y. and UEDA, Y. (1966) K-Ar dating on the igneous rocks in Japan (V)-Granitic rocks in Southwestern Japan-. J. Japan. Min. Petr. Econ. Geol. 55, 174-178 (in Japanese).

KIYOSU, Y. (1973) Sulfur isotopic fractionation among sphalerite, galena and sulfide ions. Geochem. J. 7, 191-199.

MATSUHASHI, S. (1968) Analysis of structural control and results of prospecting for bedding-plane veins in the Taishu mine. Mining Geol. 18, 161-172 (in Japanese).

Oнмото, H. (1970) Influence of $\mathrm{pH}$ and $\mathrm{fO}_{2}$ of hydrothermal fluids on the isotopic composition of sulfur species. Geol. Soc. Am. Ann. Mtg., Abs., p. 640 .

Онмото, H. (1972) Systematics of sulfur and carbon isotopes in hydrothermal ore deposits. Econ. Geol. $67,551-578$.
RoBinSON, B. W. and Oнмото, H. (1973) Mineralogy, fluid inclusions, and stable isotopes of the Echo Bay U-Ni-Ag-Cu deposits, Northwest Territories, Canada. ibid. 68, 635-656.

RoBINSON, B. W. and B ADHAM, J.P. N. (1974) Stable isotope geochemistry and the origin of the Great Bear Lake silver deposits, Northwest Territories, Canada. Can. J. Earth Sci. 11, 698-711.

RYE, R. O. and SAWKINS, F. J. (1974) Fluid inclusion and stable isotope studies on the Casapalca $\mathrm{Ag}-\mathrm{Pb}$ $\mathrm{Zn}-\mathrm{Cu}$ deposit, Central Andes, Peru. Econ. Geol. 69, 181-205.

SAKAI, H. (1968) Isotopic properties of sulfur compounds in hydrothermal processes. Geochem. J. 2, 29-49.

TAKENOUCHI, S. (1962) Polyphase inclusions in the quartz from the Taishu mine, Nagasaki Prefecture. Mining Geol. 294-297 (in Japanese).

Toulmin, P. and BARTon, P. B. (1964) A thermodynamic study of pyrite and pyrrhotite. Geochem. Cosmochim. Acta 28, 641-671.

UEHARA, Y. (1959) On the ore deposit and prospecting in the Taishu mine, Nagasaki Prefecture. Mining Geol. 9, 265-275 (in Japanese).

Uehara, Y. and Matsuhashi, S. (1961) Structural location of ore shoot at the Taishu mine, Nagasaki Prefecture, Japan. ibid. 11, 99-103 (in Japanese). 